\title{
Analisis Pengaruh Kualitas Sistem Dan Kualitas Pelayanan Terhadap Kepuasan Konsumen Dan Dampaknya Pada Kepercayaan Konsumen Pada Situs Pemesanan Tiket Pesawat
}

\author{
Rachmat Zulfikar ${ }^{1}$, Anna Mukhayaroh ${ }^{2}$, Samudi $^{3}$ \\ 1,2,3 Sistem Informasi, Universitas Nusa Mandiri \\ Email: 1rachmatz2411@nusamandiri.ac.id, ${ }^{2}$ anna.auh@nusamandiri.ac.id, \\ 3samudi.smx@nusamandiri.ac.id
}

\begin{abstract}
Abstrak
Perkembangan industri penerbangan saat ini sangat meningkat. Hal ini dapat dilihat dari semakin banyaknya maskapai penerbangan situs pemesanan tiket pesawat secara online yang bermunculan, membuat persaingan semakin kompetitif. Berangkat dari banyaknya faktor yang memengaruhi tingkat kepuasan konsumen terhadap penggunaan situs pemesanan tiket, maka dibuatlah sebuah perbandingan untuk mengetahui faktor apa saja yang memengaruhinya. Penelitian ini dilakukan menggunakan metode Analitycal Hierarchy Process (AHP) untuk mengetahui tingkat kepuasan konsumen terhadap penggunaan situs pemesanan tiket. AHP adalah metode penelitian yang digunakan untuk pengambilan suatu keputusan dengan menggunakan hierarki dan melakukan perbandingan pada setiap kriteria, serta alternatif yang menjadi pertimbangan dalam pengambilan keputusan. Setelah melakukan penelitian, maka dihasilkan jika Traveloka merupakan situs pemesanan tiket pesawat secara online yang paling diminati oleh para pengguna traveller khususnya komunitas Himpunan Pecinta Alam Lima Tangerang (HIPALITA ALL GENERATION).
\end{abstract}

Kata kunci: Analitycal Hierarchy Process, Kepuasan Konsumen, Kepercayaan Konsumen.

\begin{abstract}
The development of the aviation industry is currently very increasing. This can be seen from the increasing number of airlines online flight ticket booking sites that have sprung up, making the competition more competitive. Departing from the many factors that influence the level of consumer satisfaction with the use of ticket booking sites, a comparison is made to find out what factors influence it. This research was conducted using the Analytical Hierarchy Process (AHP) method to determine the level of consumer satisfaction with the use of ticket booking sites. AHP is a research method used for making a decision by using a hierarchy and making comparisons on each criterion, as well as alternatives that are considered in decision making. After doing research, it was found that Traveloka is the most popular online flight ticket booking site by traveler users, especially the Lima Tangerang Nature Lovers Association (HIPALITA ALL GENERATION).
\end{abstract}

Keywords: Analitycal Hierarchy Process, Consumer Satisfaction, Consumer Confidence

\section{PENDAHULUAN}

Perkembangan industri penerbangan saat ini sangat meningkat. Hal ini dapat dilihat dari semakin banyaknya maskapai penerbangan domestik dan internasional yang bermunculan sehingga membuat persaingan semakin kompetitif. Perkembangan industri penerbangan didukung dengan perkembangan teknologi informasi. Hal tersebut memiliki pengaruh pada perilaku konsumen yang menginginkan informasi yang cepat dan akurat. Internet adalah produk jasa yang sangat mudah dioperasikan dan dapat digunakan oleh semua kalangan dan juga dapat digunakan sepanjang waktu. Kelebihan itulah yang menjadi salah satu faktor pendorong berkembangnya internet di seluruh dunia (Sastika, 2016).

Saat ini internet menjadi unggulan bagi para pebisnis dalam usaha memenangkan persaingan bisnis. Ini didasari oleh meningkatnya pengguna internet di dunia yang dimana memudahkan para pebisnis 
Indonesian Journal on Software Engineering (IJSE)

Vol. 7, No. 1, Juni 2021, hlm. 100-109

untuk memasarkan dan mengembangkan lahan bisnisnya. Dengan masyarakat sebagai konsumen, konsumen dapat memilih barang atau jasa yang diinginkan selama 24 jam tanpa batas waktu serta bagi calon konsumen yang berada cukup jauh dari lokasi tidak perlu datang langsung untuk membeli barang yang di inginkan hal ini akan lebih mengehemat waktu dan biaya (Sastika, 2016).

Industri penerbangan yang didukung dengan industri teknologi informasi sangat memberikan banyak manfaat. Bagi masyarakat modern, penggunaan pesawat terbang bukan lagi sebuah kemewahan namun sudah menjadi kebutuhan primer. Ketika harus menempuh perjalanan jarak yang jauh dalam waktu yang singkat, pesawat merupakan salah satu transportasi yang akan menjadi pilihan utama oleh setiap masyarakat. Dengan perjalanan yang singkat akan menjadikan penumpang pesawat dapat menghemat waktu dan tenaga, oleh karena itu masyarakat memerlukan suatu media yang baik yang dapat memberikan informasi yang cukup untuk melakukan pilihan terhadap berbagai jenis maskapai penerbangan yang ditawarkan untuk dipakai sebagai alat menunjang pengambilan keputusan membeli tiket penerbangan (Sastika, 2016).

Harga tiket dulu bisa dikatakan masih tertutup dan hanya pihak maskapai dan agen perjalanan yang mengetahuinya, tetapi saat ini harga tiket bersifat terbuka untuk masyarakat. Saat ini, masyarakat sudah tidak perlu repot untuk pergi ke agen perjalanan maupun bandara untuk membeli tiket pesawat karena sudah banyak situs-situs dari maskapai penerbangan yang memfasilitasi pembelian tiket secara online (Sastika, 2016).

Pemesanan tiket pesawat (booking) online sudah banyak dilirik di Indonesia, terutama tak asing lagi untuk publik di kota-kota besar. Saat ini peminat online booking meningkat dan jumlah penggunanya menanjak. Kualitas dari sebuah website yang bagus itu dapat dilihat dan diukur melalui tiga dimensi kualitas website yaitu kualitas pengguna yang mencakup kemudahan untuk digunakan, dimengerti, ditelusuri, digunakan, menarik, tampilan bagus, kompetensi baik, memberi pengalaman baru yang baik. Kemudian kualitas informasi dimana mencakup hal-hal informasi yang akurat, terpercaya, up to date, sesuai topik bahasan, mudah dimengerti, detail, dan disampaikan dalam format desain yang sesuai. Dan yang terakhir kualitas interaksi yaitu mencakup kemampuan memberi rasa aman pada konsumen saat transaksi, memiliki reputasi yang baik, mampu memudahkan komunikasi, menciptakan perasaan emosional yang lebih personal, memiliki kepercayaan dalam menyimpan informasi pribadi user, menciptakan komunitas yang lebih spesifik, menepati janji yang disampaikan. Sekarang, dengan banyaknya penjualan secara online, banyak website yang bersaing dengan cara memberikan tampilan yang menarik di situs website mereka sendiri, dengan memberikan pelayanan dan informasi yang akurat sehingga para konsumen tidak ragu untuk bertransaksi untuk membeli sesuatu, dengan kualitas website yang bagus akan membuat para konsumen merasa puas melakukan transaksi melalui website tersebut, dan akhirnya konsumen akan mengunjungi website itu lagi apabila ingin melakukan pembelian secara online (Sastika, 2016).

Namun disisi lain masih terdapat konsumen yang masih mengalami kesulitan ketika menggunakan online travel agent. Berdasarkan situs mediakonsumen.com menyebutkan terdapat konsumen yang mengalami kesulitan ketika melakukan pembelian tiket perjalanan melalui salah satu online travel agency, karena tidak terbitnya e-ticket ketika sudah melakukan pembayaran. Selain itu terdapat juga ketidak amanan pada fasilitas Paylater dikarenakan adanya penyalah gunaan akun yang dirasakan oleh beberapa konsumen. Hal lain yang menjadikan permasalahan dalam penelitian kali ini adalah adanya peningkatan minat menggunakan online travel agency, terdapat kesulitan ketika menggunakan online travel agency, kurangnya keamanan pada fasilitas Paylater, selain itu adanya faktor-faktor yang mempengaruhi ketika memilih online travel agency sebagai dampak dari pemilihan online travel (Rakhmah \& Wahyuningsih, 2020).

Berbagai metode yang dipakai untuk mengatasi keluhan adalah untuk memberikan kepuasan yang optimal kepada konsumen, meningkatkan loyalitas konsumen, terhadap jasa perusahaan dalam manajemen komplain adalah bagaimana mengubah keluhan dan kritikan konsumen menjadi informasi yang berharga bagi perusahaan sehingga dapat meningkatkan kepuasan serta menciptakan loyalitas konsumen (Nugroho, 2015).

Jika perusahaan tidak ingin kehilangan para konsumen lebih banyak lagi, maka harus segera melakukan perbaikan terhadap kualitas pelayanan yang diberikan dengan cara menindaklanjuti keluhankeluhan dari konsumen agar tidak terjadi pada kemudian hari. Maka pihak manajemen harus melakukan strategi-strategi baru agar dapat mengurangi keluhan dari konsumen dan juga untuk mendapatkan kepercayaan konsumen serta memberikan kualitas pelayanan yang lebih baik bagi semua pelanggannya. Diharapkan dari penelitian ini dapat diketahui faktor-faktor yang mempengaruhi kepuasan konsumen terhadap pelayanan pengaruh kualitas sistem dan kualitas pelayanan terhadap kepuasan konsumen dan dampaknya pada kepercayaan konsumen pada situs pemesanan tiket pesawat. 


\section{METODE PENELITIAN}

\section{A. Tahapan Penelitian}

Tahapan dalam penyusunan penelitian ini ditunjukan pada gambar 1

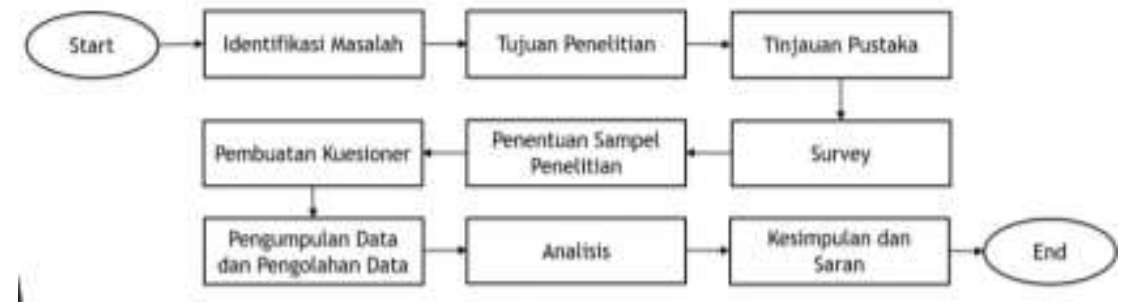

Sumber: Hasil Penelitian (2020)

Gambar 1. Alur Tahapan Penelitian

1)

Adapun tahapan penelitian yang dilakukan adalah sebagai berikut: Identifikasi Masalah

Langkah pertama yang dilakukan dalam menelitian ini adalah mengidentifikasikan masalah yang ada, sehingga hasilnya tidak keluar dari alur penelitian.

2) Tujuan Penelitian

Selanjutnya, yang dilakukan dalam penelitian ini adalah menganalisa pengaruh kualitas sistem dan kualitas pelayanan terhadap kepuasan konsumen dan dampaknya pada kepercayaan konsumen pada situs pemesanan tiket pesawat

3) Tinjauan Pustaka

Tinjauan Pustaka ditujukan untuk mendapatkan teori-teori dari para ahli dan pakar pada bidangnya masing-masing dan hasil dari penelitian yang terlebih dahulu dilakukan sebagai acuan untuk penelitian ini dan yang akan dijadikan landasan pada penelitian ini.

a. Pengambilan Keputusan

Pengambilan keputusan didalam suatu organisasi merupakan hasil suatu proses komunikasi dan partisipasi yang terus menerus dari keseluruhan organisasi. Hasil keputusan tersebut dapat merupakan pernyataan yang disetujui alternatif atau antar prosedur untuk mencapai tujuan tertentu (Rakhmah \& Wahyuningsih, 2020). Perlu adanya suatu proses-proses yang harus dilalui untuk mengambil suatu keputusan, disarankan anda mengikuti proses pengambilan keputusan. Simon mengatakan bahwa proses tersebut meliputi 3 fase utama, yaitu Intelligence, Design dan Choice, kemudian Simon menambahkan fase keempat, yaitu Implementation (Pradipta \& Diana, 2017). Pengambilan keputusan didalam suatu organisasi merupakan hasil suatu proses komunikasi dan partisipasi yang terus menerus dari keseluruhan organisasi. Hasil keputusan tersebut dapat merupakan pernyataan yang disetujui alternatif atau antar prosedur untuk mencapai tujuan tertentu (Firatmadi, 2017).

b. Analytical Hierarchy Process (AHP)

Proses pengambilan keputusan pada dasarnya adalah memilih suatu alternatif. Peralatan utama AHP adalah sebuah hierarki fungsional dengan input utamanya persepsi manusia. Keberadaan hierarki memungkinkan dipecahnya masalah kompleks atau tidak terstruktur dalam sub - sub masalah, lalu menyusunnya menjadi suatu bentuk hierarki (Arifin, 2010).

c. Kualitas Layanan

Kualitas mencerminkan semua dimensi penawaran produk yang menghasilkan manfaat (benefit) bagi pelanggan. Istilah nilai (value) seringkali digunakan sebagai acuan terhadap kualitas relatif suatu produk dan harga dari produk tersebut. Kualitas layanan merupakan hal yang penting bagi suatu perusahaan, karena dengan pelayanan yang baik akan membuat konsumen memiliki kemudahan pengambilan keputusan dalam melakukan pembelian pada suatu produk. Kualitas layanan merupakan salah satu hal yang dapat mempengaruhi konsumen dalam memutuskan untuk melakukan pembelian, baik secara tradisional atau secara online (Mal et al., 2018). 


\section{d. Penjualan Tiket Online}

Internet merupakan salah satu teknologi yang banyak digunakan untuk memasarkan produknya, termasuk oleh perusahaan agen penjualan tiket penerbangan. Hal ini mulai dilirik oleh agent travel offline dalam melakukan penjualan tiket, semakin merebaknya agen penjualan tiket online seperti traveloka, tiket10.com, tiket.com, pegi-pegi.com dan lain-lainnya, membuat konsumen semakin dimanjakan dengan tekonologi ini. Berbagai kemudahan yang ditimbulkan akibat bisnis yang dijalankan secara online tidak secara otomatis mengakibatkan pembeli membeli produk secara online termasuk pembelian tiket pesawat secara online (Sitorus et al., 2018).

4) Survey

Dalam konteks ini dimaksudkan untuk mengetahui hal-hal penting yang berbungan dengan penelitian untuk dijadikan sebagai masukan. Survey ini dilakukan dengan cara menyebarkan kuesioner kepada kalangan komunitas traveller.

5) Penentuan Sampel Penelitian

Dalam penelitian ini pihak yang dijadikan sampel penelitian (responden) yaitu 43 orang dalam komunitas travelling.

6) Pembuatan kuesioner

Pembuatan kuesioner dilakukan penulis guna memperoleh sebuah data yang dapat mendukung penelitian ini. Dalam pembuatan kuesioner harus berupa pertanyaan yang terstruktur dan berhubungan dengan masalah yang ingin diteliti.

7) Pengumpulan dan pengolahan data

Data yang digunakan dalam penelitian ini adalah data yang didapat dari pengguna jasa tiket pesawat secara online melalui pengisian kuesioner. Teknik penggumpulan data dalam penelitian ini dilakukan dengan menggunakan metode pengambilan sampel, dimana setiap elemen populasi memiliki probabilitas terpilih yang sama.

8) Analisis

Selanjutnya adalah menganalis hasil pengumpulan data juga pengolahan data. Analisis diupayakan cukup mendalam sehingga dapat menghasilkan kumpulan data yang valid.

9) Kesimpulan dan saran

Tahapan terakhir dari penelitian ini adalah kesimpulan. Dengan menarik kesimpulan dari hasil pengolahan data dan analisis untuk mengetahui kualitas pelayanan terhadap konsumen dan dampaknya terhadap kepercayaan konsumen pada situs pemesanan tiket pesawat.

\section{B. Metode Pengumpulan Data, Populasi dan Sample Penelitian}

1. Pengumpulan Data

Adapun data-data yang digunakan dalam penelitian ini adalah data yang didapat dari pengguna kuesioner yang telah disebarkan dan kemudian diisi oleh para responden sebagai acuan untuk pengolahan data.

Setelah melakukan penyebaran kuesioner kepada responden maka dilakukan uji kecakupan data. Perhitungan kecakupan data dimaksudkan untuk menentukan jumlah sampel minimun yang dapat diolah untuk proses perhitungan selanjutnya. Perhitungan ini dilakukan untuk melihat apakah yang telah dikumpulkan sudah cukup atau belum. Bila data yang didapatkan belum cukup maka proses pengambilan data harus dilakukan kembali. Data yang dikumpulkan sudah dianggap cukup maka langkah selanjutnya adalah melakukan pengolahan data.

\section{Populasi}

Populasi dalam penelitian ini adalah para responden yang menggunakan atau yang sering melakukan pembelian tiket pesawat secara online di sebuah situs website travel online dalam kurun waktu 1 tahun terakhir.

\section{Sampel Penelitian}

Pengambilan sampel dalam penelitian ini adalah menyebar kuesioner kepada komunitas travelling yang sering melakukan pembelian tiket pesawat secara online yang ada. Pada penelitian ini untuk jumlah responden adalah 43 , yang artinya mengambil seluruh populasi dalam komunitas tesebut. 


\section{Metode Analisis Data}

Analisa merupakan bagian penting dalam metodologi penelitian ilmiah, dikarenakan dengan melakukan analisis, data tersebut dapat diberi arti dan makna yang berguna dalam suatu penyelesaian masalah. Metode Analytical Hierarchy Process (AHP) merupakan metode pengambilan keputusan yang komprehensif. Metode ini memperhitungkan hal-hal kualitatif dan kuantitatif sekaligus.

Laporan disusun dari rangkuman semua sumber-sumber tersebut dengan dukungan teori yang ada, menjadi uraian analisis. Tahap analisis dalam pendekatan ini sudah dimulai sejak penelitian dan data pertama telah diperoleh. Sedangkan penelitian kuantitatif menggunakan angket dan data-data yang berupa angka, tabulasi, perhitungan-perhitungan menggunakan sejumlah metode analisis matematik/statistik yang hasilnya menjadi dasar pijakan untuk mengambil keputusan atau kesimpulan. Data dari pendekatan kuantitatif lebih banyak berbentuk angka dan tabel. Sementara itu, tahap analisis hanya dapat dilakukan jika data telah terkumpul dengan lengkap dan tersaji dalam tabulasi yang siap diolah secara statistik (Zaluchu, 2020).

\section{Analytical Hierarchy Process (AHP) Sebagai Teori Pengambilan Keputusan}

Dalam mengambil keputusan, AHP mempunyai kriteria sebagai dasar penilaian, dan kita juga akan dihadapkan dengan lebih dari satu alternative pilihan. Jika alternative pilihan tersebut hanya ada dua, mungkin masih mudah buat kita untuk memilih, akan tetapi jika alternative pilihan tersebut banyak, maka cukup sulit bagi kita untuk memutuskannya.

Pengambilan keputusan merupakan kegiatan yang sering dilakukan dalam kehidupan sehari-hari, dalam kasus sederhana, otak mampu mengatasi proses tersebut. Namun masalahnya menjadi kompleks takala suatu keputusan menyangkut banyak kriteria atau banyak pilihan. Oleh karena itu, dirasa perlu adanya alat bantu yang memudahkan seseorang dalam pengambilan keputusan.

Penulis menggunakan metode Analytical Hierarchy Process (AHP) sebagai metode pengambilan keputusan, untuk sistem pendukung keputusan yang dibangun. Metode AHP merupakan salah satu metode dalam proses pengambilan keputusan, yang dibangun berdasarkan tiga prinsip, yaitu prinsip penyusunan hirarki, prinsip penetapan prioritas, dan prinsip konsistensi (Prasetyo \& Kusumah, 2015).

Agar solusi yang dihasilkan optimal maka konsistensi metode AHP harus tetap terjaga. Dalam mengetahui tingkat konsistensi tersebut, penggunaan metode AHP akan diukur dengan besarnya CR (Consistency Ratio). CR (Consistency Ratio) adalah hasil perbandingan antara Indeks Consistency (Cl) dengan Random Indeks (RI). Apabila hasil CR adalah $\leq 0.10$ maka derajat konsistensinya optimal. Sebaiknya, jika CR adalah > 0.10 maka terdapat ketidakkonsistenan dalam menentukan perbandingan, yang memungkinkan solusi yang dihasilkan dari metode AHP tidak berarti. Random index (RI) yang nilainya untuk setiap ordo matriks dapat dilihhat pada table ini.

Tabel 1. Indeks Random Konsistensi

\begin{tabular}{lllllllllll}
\hline $\mathbf{0}$ & $\mathbf{1}$ & $\mathbf{2}$ & $\mathbf{3}$ & $\mathbf{4}$ & $\mathbf{5}$ & $\mathbf{6}$ & $\mathbf{7}$ & $\mathbf{8}$ & $\mathbf{9}$ & $\mathbf{1 0}$ \\
\hline $\mathbf{R I}$ & 0,00 & 0,00 & 0,58 & 0,9 & 1,12 & 1,24 & 1,32 & 1,41 & 1,45 & 1,49 \\
\hline \multicolumn{8}{c}{ Sumber: (Prasetyo \& Kusumah, 2015$)$}
\end{tabular}

Dengan tetap menggunakan matriks diatas, pendekatan yang digunakan untuk pengujian konsistensi matriks perbandingan adalah melakukan perkalian antara bobot elemen dengan nilai awal matriks dengan bobot untuk mendapatkan nilai eigen.

Untuk menjamin bahwa keputusan yang telah ditetapkan oleh pengambil keputusan konsisten rasio Inkonsistensi data akan dianggap baik jika nilai rasio konsistensi atar $C R \leq 0,10$. Saaty telah membuktikan bahwa indeks konsistensi dari matriks $\mathrm{n}$ dapat diperoleh dengan rumus:

$$
C I=\frac{\lambda \max -n}{n-1}
$$

Keterangan:

$\mathrm{Cl} \quad$ : Indeks Konsistensi (Consistency index)

$\lambda \max :$ Nilai eigen terbesar dari matriks berordo $\mathrm{n}$

$\mathrm{n} \quad$ : Orde matriks

Dimana $\mathrm{n}$ adalah jumlah elemen yang hendak dibandingkan dengan $\lambda$ max adalah eigen value terbesar. Kemudian hitung $\mathrm{CR}$, yaitu $\mathrm{Cl}$ dibagi dengan random index (RI).

Sedangkan rasio kosistensi dapat diitung dengan menggunakan rumus sebagai berikut:

$$
C R=\frac{C I}{R I}
$$


Indonesian Journal on Software Engineering (IJSE)

Vol. 7, No. 1, Juni 2021, hlm. 100-109

\section{Keterangan:}

CR :Rasio Konsistensi (Consistency Ratio)

Cl :Indeks Konsistensi (Consistency Index)

RI :Indeks Acak (Random index)

Untuk mengukur keakuratan jawaban responden, AHP menggunakan indikator konsistensi rasio.

Indikator ini diusahakan rasio. Indikator ini diusahakan tidak lebih dari 10 persen. Jika batasan ini tidak terpenuhi, maka jawaban responden perlu direvisi.

\section{HASIL DAN PEMBAHASAN}

Pada bagian ini, dijelaskan hasil penelitian dan pada saat yang sama diberikan pembahasan yang komprehensif dan ditekankan nilai baru dari penelitian yang memuat inovasi, serta implikasinya. Hasil dapat disajikan dengan gambar, grafik, tabel dan lainnya agar pembaca dapat dengan mudah memahami.

Penelitian ini menggunakan metode Analytical Hierarchy Process (AHP) untuk menentukan hasil penelitian dan pembahasan. Prinsip-prinsip dasar dari metode Analytical Hierarchy Process (AHP) adalah Decompotition, Comparative Judgement, Synthesis of Priority, dan Consistency. Berdasarkan hasil pengisian kuesioner yang telah disebarkan kepada responden, kemudian dibuat dalam bentuk matriks perbandingan berpasangan untuk mendapatkan bobot dari kriteria masing-masing. Data penelitian diperoleh dari kuesioner yang diisi oleh 43 responden pengguna travel online. Kriteria yang digunakan yaitu harga, kepercayaan, kualitas dan kemudahan. Untuk lebih mempermudah dalam perhitungannya, maka dibuatlah dalam bentuk tabel dari setiap elemennya didesimalkan berdasarkan matriks perbandingan yang telah dibuat maka data-data tersebut dapat diolah untuk memperoleh indeks konsistensi dan rasio konsistensi.

\section{1) Struktur Hierarki}

Bersumber dari hasil kuisioner yang telah disebarkan kepada para responden maka terlihat kriteria dan alternatif yang telah diambil, kemudian disusunlah dalam sebuah bentuk hierarki agar lebih mempermudah dalam pengolahan data. Berikut adalah hierarki untuk mengetahui pengaruh kualitas sistem dan kualitas pelayanan terhadap kepuasan konsumen dan dampaknya pada kepercayaan konsumen pada situs pemesanan tiket pesawat secara online.

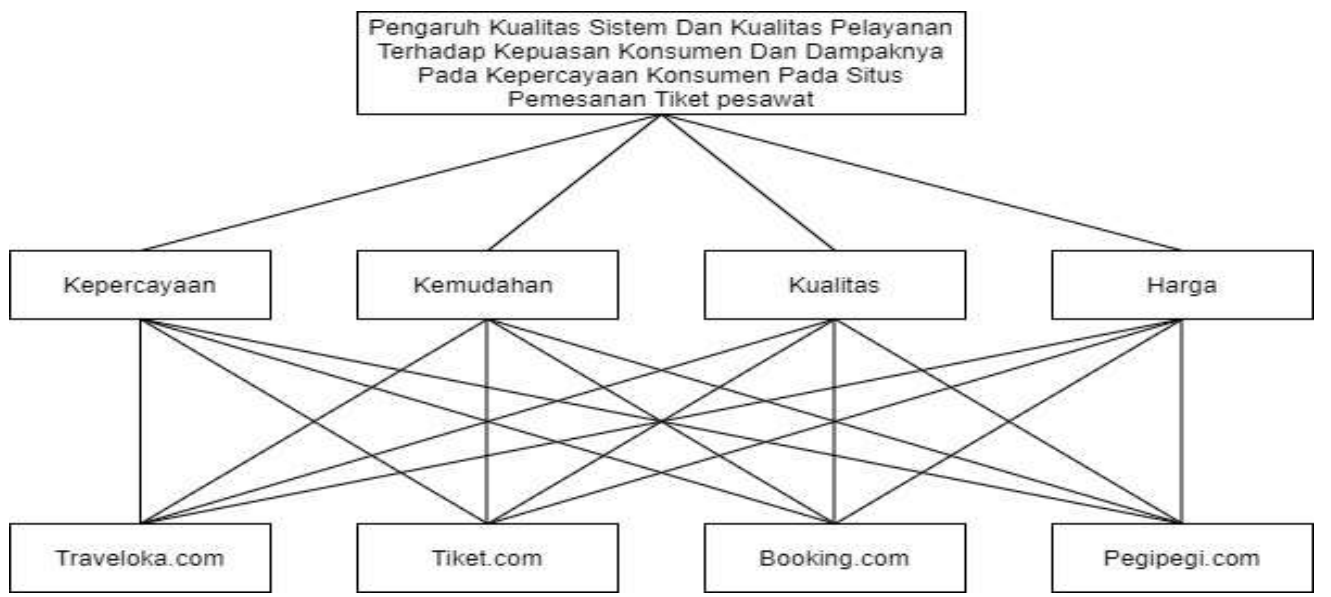

Sumber: Hasil Penelitian (2020)

\section{2) Perhitungan Kriteria Utama}

Gambar 2. Struktur Hierarki

Berdasarkan data yang diperoleh dari 43 responden, diperoleh matriks perbandingan berpasangan pada kriteria utama di dapat perbandingan masing-masing kriteria sebagai berikut:

Tabel 2. Matriks Berpasangan Kriteria Utama 


\begin{tabular}{lllll} 
& Harga & Kepercayaan & Kualitas & Kemudahan \\
\hline Harga & 1,000 & 0,430 & 0,489 & 1,148 \\
Kepercayaan & 2,323 & 1,000 & 1,712 & 4,042 \\
Kualitas & 2,047 & 0,584 & 1,000 & 3,629 \\
Kemudahan & 0,871 & 0,247 & 0,276 & 1,000 \\
Jumlah & 6,241 & 2,262 & 3,476 & 9,819 \\
\hline
\end{tabular}

Sumber: Hasil Penelitian (2020)

Tabel 3. Matriks Faktor Pembobotan Hierarki Untuk Semua Kriteria Yang Dinormalkan

\begin{tabular}{lllllll}
\hline & Harga & Kepercayaan & Kualitas & Kemudahan & Jumlah & $\begin{array}{l}\text { Eigen } \\
\text { Vector } \\
\text { (EV) }\end{array}$ \\
\hline Harga & 0,160 & 0,190 & 0,141 & 0,117 & 0,608 & 0,152 \\
Kepercayaan & 0,372 & 0,442 & 0,492 & 0,412 & 1,718 & 0,430 \\
Kualitas & 0,328 & 0,258 & 0,288 & 0,370 & 1,244 & 0,311 \\
Kemudahan & 0,140 & 0,109 & 0,079 & 0,102 & 0,430 & 0,108 \\
\hline
\end{tabular}

Sumber: Hasil Penelitian (2020)

Berdasarkan nilai eigen vector maka dapat disimpulkan bahwa urutan faktor kriteria utama yang mempengaruhi bahwa Kepercayaan merupakan yang paling berpengaruh terhadap kepuasan dan kepercayaan konsumen terhadap situs website pemesanan tiket secara online dengan nilai bobot 0,430 atau $42,96 \%$ berikutnya adalah kualitas dengan nilai bobot 0,311 atau $31,09 \%$ selanjutnya harga dengan bobot nilai 0,152 atau $15,20 \%$ dan yang terakhir kemudahan dengan bobot nilai 0,108 atau $10,75 \%$. Berdasarkan hasil diatas maka didapatkan nilai konsistensi kriteria adalah:

$$
=\frac{0,019}{0,9} C R \quad=\frac{C I}{R I}=0,021
$$

Berdasarkan nilai tersebut maka Rasio Konsistensi pada Kriteria Utama adalah kurang dari 0,1 maka dapat diartikan konsisten.

3) Perhitungan Kriteria Harga

\begin{tabular}{lllll} 
& \multicolumn{4}{c}{ Tabel 4. Matriks Berpasangan Kriteria Harga } \\
\hline & Traveloka.com & Tiket.com & Pegipegi.com & Booking.com \\
\hline Traveloka & 1,000 & 1,818 & 3,547 & 3,506 \\
Tiket.com & 0,550 & 1,000 & 2,258 & 2,426 \\
Pegipegi & 0,282 & 0,443 & 1,000 & 1,229 \\
Booking.com & 0,285 & 0,412 & 0,814 & 1,000 \\
Jumlah & 2,117 & 3,673 & 7,618 & 8,161 \\
\hline
\end{tabular}

Sumber: Hasil Penelitian (2020)

Tabel 5. Matriks Faktor Kriteria Harga Yang Dinormalkan

\begin{tabular}{lllllll}
\hline & Traveloka & Tiket.com & Pegipegi & Booking.com & Jumlah & $\begin{array}{l}\text { Eigen } \\
\text { Vector (EV) }\end{array}$ \\
\hline Traveloka & 0,472 & 0,495 & 0,466 & 0,430 & 1,862 & 0,466 \\
Tiket.com & 0,260 & 0,272 & 0,296 & 0,297 & 1,126 & 0,281 \\
Pegipegi & 0,133 & 0,121 & 0,131 & 0,151 & 0,536 & 0,134 \\
Booking.com & 0,135 & 0,112 & 0,107 & 0,123 & 0,476 & 0,119 \\
\hline
\end{tabular}

Sumber: Hasil Penelitian (2020)

Berdasarkan nilai eigen vector maka dapat disimpulkan bahwa urutan alternatif untuk Harga adalah Traveloka dengan nilai bobot 0,466 atau $46,56 \%$, Tiket.com dengan nilai bobot 0,281 atau $28,14 \%$, Pegipegi dengan bobot nilai 0,134 atau 13,39\%, dan yang terakhir Booking.com dengan bobot nilai 0,119 atau $11,91 \%$. 
Indonesian Journal on Software Engineering (IJSE)

Vol. 7, No. 1, Juni 2021, hlm. 100-109

\section{4) Perhitungan Kriteria Kepercayaan}

Tabel 6. Matriks Berpasangan Kriteria Kepercayaan

\begin{tabular}{lllll}
\hline & Traveloka.com & Tiket.com & Pegipegi.com & Booking.com \\
\hline Traveloka & 1,000 & 1,922 & 3,240 & 2,789 \\
Tiket.com & 0,520 & 1,000 & 2,275 & 2,684 \\
Pegipegi & 0,309 & 0,440 & 1,000 & 1,705 \\
Booking.com & 0,359 & 0,373 & 0,586 & 1,000 \\
Jumlah & 2,187 & 3,734 & 7,101 & 8,178 \\
\hline
\end{tabular}

Sumber: Hasil Penelitian (2020)

Tabel 7. Matriks Faktor Kriteria Kepercayaan Yang Dinormalkan

\begin{tabular}{lllllll}
\hline & Traveloka & Tiket.com & Pegipegi & Booking.com & Jumlah & $\begin{array}{l}\text { Eigen Vector } \\
\text { (EV) }\end{array}$ \\
\hline Traveloka & 0,457 & 0,515 & 0,456 & 0,341 & 1,769 & 0,442 \\
Tiket.com & 0,238 & 0,268 & 0,320 & 0,328 & 1,154 & 0,289 \\
Pegipegi & 0,141 & 0,118 & 0,141 & 0,209 & 0,608 & 0,152 \\
Booking.com & 0,164 & 0,100 & 0,083 & 0,122 & 0,469 & 0,117 \\
\hline
\end{tabular}

Sumber: Hasil Penelitian (2020)

Berdasarkan nilai eigen vector maka dapat disimpulkan bahwa urutan alternatif untuk Kepercayaan adalah Traveloka dengan nilai bobot 0,442 atau 44,25\%, Tiket.com dengan nilai bobot 0,289 atau $28,85 \%$, Pegipegi dengan bobot nilai 0,152 atau 15,20\% dan yang terakhir Booking.com dengan bobot nilai 0,117 atau $11,71 \%$.

5) Perhitungan Kriteria Kualitas

Tabel 8. Matriks Perbandingan Kriteria Kualitas

\begin{tabular}{lllll}
\hline & Traveloka.com & Tiket.com & Pegipegi.com & Booking.com \\
\hline Traveloka & 1,000 & 1,599 & 3,099 & 3,051 \\
Tiket.com & 0,625 & 1,000 & 2,614 & 2,925 \\
Pegipegi & 0,323 & 0,382 & 1,000 & 1,360 \\
Booking.com & 0,328 & 0,342 & 0,735 & 1,000 \\
Jumlah & 2,276 & 3,324 & 7,448 & 8,336 \\
\hline \multicolumn{5}{c}{ Sumber: Hasil Penelitian (2020) }
\end{tabular}

Tabel 9. Matriks Faktor Kriteria Kualitas Yang Dinormalkan

\begin{tabular}{lllllll}
\hline & Traveloka & Tiket.com & Pegipegi & Booking.com & Jumlah & Eigen Vector (EV) \\
\hline Traveloka & 0,439 & 0,481 & 0,416 & 0,366 & 1,703 & 0,426 \\
Tiket.com & 0,275 & 0,301 & 0,351 & 0,351 & 1,278 & 0,319 \\
Pegipegi & 0,142 & 0,115 & 0,134 & 0,163 & 0,554 & 0,139 \\
Booking.com & 0,144 & 0,103 & 0,099 & 0,120 & 0,466 & 0,116 \\
\hline
\end{tabular}

Sumber: Hasil Penelitian (2020)

Berdasarkan nilai eigen vector maka dapat disimpulkan bahwa urutan alternatif untuk Kualitas adalah Traveloka dengan nilai bobot 0,426 atau $42,56 \%$, Tiket.com dengan nilai bobot 0,319 atau $31,94 \%$, Pegipegi dengan bobot nilai 0,139 atau $13,86 \%$ dan yang terakhir Booking.com dengan bobot nilai 0,116 atau $11,64 \%$.

6) Perhitungan Kriteria Kemudahan

Tabel 10. Matriks Perbandingan Kriteria Kemudahan

\begin{tabular}{lllll}
\hline & Traveloka.com & Tiket.com & Pegipegi.com & Booking.com \\
\hline Traveloka & 1,000 & 2,230 & 2,815 & 2,762 \\
Tiket.com & 0,449 & 1,000 & 1,404 & 1,832 \\
Pegipegi & 0,355 & 0,712 & 1,000 & 1,350 \\
Booking.com & 0,362 & 0,546 & 0,741 & 1,000 \\
Jumlah & 2,166 & 4,487 & 5,960 & 6,944 \\
\hline \multicolumn{5}{c}{ Sumber: Hasil Penelitian (2020) } \\
\hline
\end{tabular}

Sumber: Hasil Penelitian (2020) 


\begin{tabular}{lllllll}
\hline \multicolumn{7}{c}{ Tabel 11. Matriks Kriteria Kemudahan Yang Dinormalkan } \\
& Traveloka & Tiket.com & Pegipegi & Booking.com & Jumlah & $\begin{array}{l}\text { Eigen Vector } \\
\text { (EV) }\end{array}$ \\
\hline Traveloka & 0,462 & 0,497 & 0,472 & 0,398 & 1,829 & 0,457 \\
Tiket.com & 0,207 & 0,223 & 0,236 & 0,264 & 0,929 & 0,232 \\
Pegipegi & 0,164 & 0,159 & 0,168 & 0,194 & 0,685 & 0,171 \\
Booking.com & 0,167 & 0,122 & 0,124 & 0,144 & 0,557 & 0,139 \\
\hline
\end{tabular}

Sumber: Hasil Penelitian (2020)

Berdasarkan nilai eigen vector maka dapat disimpulkan bahwa urutan alternatif untuk Kualitas adalah Traveloka dengan nilai bobot 0,457 atau $42,71 \%$, Tiket.com dengan nilai bobot 0,232 atau $23,24 \%$, Pegipegi dengan bobot nilai 0,171 atau 17,12\% dan yang terakhir Booking.com dengan bobot nilai 0,139 atau $13,93 \%$.

\section{7) Hasil Akhir Penelitian}

Tabel 12. Hasil Perhitungan Akhir

\begin{tabular}{lllll}
\hline & Traveloka.com & Tiket.com & Pegipegi.com & Booking.com \\
\hline Harga & 0,466 & 0,281 & 0,134 & 0,119 \\
Kepercayaan & 0,442 & 0,289 & 0,152 & 0,117 \\
Kualitas & 0,426 & 0,319 & 0,139 & 0,116 \\
Kemudahan & 0,457 & 0,232 & 0,171 & 0,139 \\
Jumlah & 1,791 & 1,122 & 0,596 & 0,492 \\
\hline
\end{tabular}

Sumber: Hasil Penelitian (2020)

Dari perhitungan tersebut dihasilkan jika Traveloka merupakan situs pemesanan tiket pesawat secara online yang paling diminati oleh para pengguna traveller khususnya komunitas Himpunan Pecinta Alam Lima Tangerang (HIPALITA ALL GENERATION) dengan perolehan nilai 1,791 atau sama dengan $44,77 \%$. Kemudian pilihan kedua yang banyak diminati adalah Tiket.com dengan perolehan nilai 1,122 atau sama dengan $28,04 \%$. Selanjutnya Pegipegi dengan bobot nilai 0,596 atau $14,89 \%$ dan yang terakhir Booking.com dengan bobot nilai 0,492 atau 12,30\%.

\section{KESIMPULAN}

Berdasarkan hasil penelitian dan pembahasan yang dilakukan dapat disimpulkan beberapa hal, yaitu untuk mengetahui dampak yang mempengaruhi terhadap penggunaan situs pemesanan tiket pesawat secara online dengan menggunakan metode Analytical Hierarchy Process (AHP) dapat memudahkan para pengguna jasa pemesanan tiket secara online untuk memilih situs pemesanan tiket secara online manakah yang paling bagus, sesuai dengan kriteria harga, kepercayaan, kualitas, dan kemudahan. Hasil penelitian ini menunjukkan bahwa kriteria kepercayaan adalah faktor yang sangat berpengaruh terhadap konsumen ketika memilih online situs pemesanan tiket pesawar secara online dengan presentase 42,96\%, kemudian disusul oleh kriteria kualitas 31,09\%, kriteria harga 15,20\%, kriteria kemudahan $10,75 \%$. Berdasarkan hasil keseleruhan alternatif yang paling diminati adalah Traveloka dengan presentase $44,77 \%$, kemudian Tiket.com $28,04 \%$, Pegipegi $14,89 \%$ dan yang terakhir Booking.com $12,30 \%$. Hasil CR untuk kriteria menunjukkan nilai $\leq 0,1$ atau kurang dari $10 \%$ maka hierarki secara keseluruhan bersifat konsisten.

\section{REFERENSI}

Arifin, Z. (2010). Penerapan Metode Analytical Hierarchy Process (AHP) Untuk Menentukan Sisa Hasil Usaha Pada Koperasi Pegawai Negeri. Jurnal Informatika Mulawarman, 5(2), 1-12.

Firatmadi, A. (2017). Pengaruh Kualitas Pelayanan dan Persepsi harga terhadap Kepuasan Pelanggan serta Dampaknya terhadap Loyalitas Pelanggan. Journal of Business Studies, 2(2), 2443-3837. http://journal.uta45jakarta.ac.id/index.php/jbsuta/article/viewFile/959/667

Mal, L. H., Gede, I., \& Mertayasa, A. (2018). Traveloka.Com Pada Mahasiswa Program Studi Manajemen Fakultas Ekonomika Dan Humaniora Universitas Dhyana Pura Bali. Jurnal Ekonomi Dan Pariwisata, 13(1), 63-73.

Nugroho, M. K. (2015). PENERAPAN MANAJEMEN KOMPLAIN PADA LAYANAN JASA DI PDAM TIRTA LAWU KARANGANYAR. In UNIVERSITAS SEBELASMARET (Vol. 151, Issue 1, pp. 10-17). Pradipta, A. Y., \& Diana, A. (2017). Sistem Penunjang Keputusan Pemilihan Supplier pada Apotek 
Indonesian Journal on Software Engineering (IJSE)

Vol. 7, No. 1, Juni 2021, hlm. 100-109

Akreditasi KEMENRISTEKDIKTI, No. 85/M/KPT/2020

dengan Metode AHP dan SAW (Studi Kasus Apotek XYZ). SISFOTEK, 1(1), 107-114.

Prasetyo, T. F., \& Kusumah, C. (2015). Sistem Pendukung Keputusan Mahasiswa Berprestasi Menggunakan Metode Analytical Hierarchy Process (Ahp). J-Ensitec, 2(01), 82-93. https://doi.org/10.31949/j-ensitec.v2i01.51

Rakhmah, S. N., \& Wahyuningsih, S. (2020). Penentuan Faktor Prioritas Pemilihan Online Travel Agency di Wilayah Bekasi Menggunakan Metode Analytical Hierarchy Process. Jurnal Media Informatika Budidarma, 4(3), 825. https://doi.org/10.30865/mib.v4i3.2268

Sastika, W. (2016). Analisis Pengaruh Kualitas Website (WebQual 4.0) Terhadap Keputusan Pembelian pada Website e-commerce Traveloka. Sentika, 2016(Sentika), 18-19.

Sitorus, P. P., Keke, Y., \& Sitorus, M. R. (2018). Faktor - Faktor Yang Mempengaruhi Keputusan Pembelian Tiket Pesawat Pada Online Travel Agent. Manajemen Bisnis Transportasi Dan Logistik, 4(2), 141-146.

Zaluchu, S. E. (2020). Strategi Penelitian Kualitatif dan Kuantitatif Di Dalam Penelitian Agama. Evangelikal: Jurnal Teologi Injili Dan Pembinaan Warga Jemaat, 4(1), 28. https://doi.org/10.46445/ejti.v4i1.167 